\title{
Hydrothermal crystallization of $\mathrm{MnSiO}_{3}$ polymorphs
}

\author{
Hitoshi MomoI \\ Department of Geology, Kyushu University, Fukuoka 812
}

\begin{abstract}
Two polymorphs of $\mathrm{MnSiO}_{3}$, pyroxmangite and rhodonite, were examined with the conventional hydrothermal technique. Pyroxmangite was synthesized in the temperature lower than about $700^{\circ} \mathrm{C}$ and rhodonite in the higher temperature. Synthetic and natural pyroxmangites transform into rhodonite at about $700^{\circ} \mathrm{C}$ as temperature rises. However, the reverse reaction from rhodonite to pyroxmangite were tried but no transformation was recognized by the X-ray diffraction technique.

The crystallization processes of $\mathrm{MnSiO}_{3}$ were investigated using three different starting materials under a water pressure of $2 \mathrm{~kb}$. In the crystallization of pyroxmangite, at $650^{\circ} \mathrm{C}$, a clinopyroxene-like phase appeared as an intermediate phase, changes to pyroxmangite which further transforms into rhodonite at $750^{\circ} \mathrm{C}$.

Structural changes in the transformation of pyroxmangite to rhodonite with rising temperature or increasing duration time may be regarded as a decrease of the number of silica tetrahedra in a repeat unit of a single chain. There seems to be the same relationship anong clinopyroxene and pyroxenoids, when clinopyroxene is regarded as a kind of pyroxenoid having a side-step after an infinite repetition of two silica tetrahedra unit along the single chain.
\end{abstract}

\section{Introduction}

Four polymorphs have been known for the composition of $\mathrm{MnSiO}_{3}$. They are rhodonite, pyroxmangite, clinopyroxene, and a garnet-like phase. Under dry conditions of high temperature and one atm. pressure, rhodonite is an only stable phase known so far and its melting temperature was determined by Glasser (1958). Under hydrothermal conditions, two phases of rhodonite and pyrox- 
mangite were obtained by Momoi (1968) and Ito (1973). Also, Peters (1971) has determined the univariant curves from rhodochrosite and quartz to pyroxmangite under various atmospheres by mixing water and carbon dioxide. Under high pressures above $20 \mathrm{~kb}$, clinopyroxene and garnet together with rhodonite and pyroxmangite were synthesized and their stability relations were determined by Akimoto and Syono (1972).

The natural occurrences of pyroxmangite in vein- and beddedform manganese ore deposits suggest that there would be a stability field of pyroxmangite under hydrothermal conditions of comparatively low temperature and pressure. The data obtained by hydrothermal experiments seem to be consistent with the natural occurrences of pyroxmangite. Thus, there is an apparent discrepancy on the phases being produced between the experiment under high pressure and that under hydrothermal condition. The present reconnaissance study has been made primarily in order to get a clue to elucidate the discrepany. The hydrothermal transformation of pyroxmangite into rhodonite is also examined along with the crystallization process of $\mathrm{MnSiO}_{3}$ using various starting materials. The intermediate and end products are described and discussed in connection with the transformations among pyroxene and pyroxenoids.

\section{Experimental procedure}

Conventional hydrothermal techniques using Tuttle's bomb were employed throughout the investigation. Most of the runs were performed in the folded or welded capsules under unbuffered condition. Welding was done by torch of oxygen and propane gases. Buffered technique of Eugster (1957) was used with solid buffers of HM, NNO and MW.

Three starting materials were prepared: (1) The carbonate mixture prepared by mixing analytical grade rhodochrosite and 
silica gel in acetone, (2) the quartz and braunite mixture by heating the carbonate mixture at $800^{\circ} \mathrm{C}$ in air, and (3) the brown glass by melting the carbonate mixture at $1400^{\circ} \mathrm{C}$ in air and pulverizing it in acetone.

Temperature was maintained with the proportional on-off controller and read with the alumel-chromel thermocouple within $\pm 5^{\circ} \mathrm{C}$ accuracy. Pressure was measured on the bourdon gauge with the accuracy of $\pm 0.05 \mathrm{~kb}$.

The products were identified by means of binoculars polarized microscope, X-ray powder diffractometer and infrared absorption spectrometer.

Indexing of the X-ray powder data of pyroxenoids is generally very difficult (Chao et al., 1970). In this study, indexing was made by the trial and error method using alternately two FORTRAN computing programs. One was written in order to calculate possible reflections by $K \alpha_{1}, K \alpha_{2}$ and $K \beta$ radiations from cell dimensions, and the other to calculate cell dimensions by the method of leastsquares from the indexed powder data, employing the program by Appleman (Evans et al., 1963) and that in the UNICS system (Sakurai, 1967). For dubious indices of reflections, zero value was initially given for weights in the least-squares refinements. For the other indices, adequate values were given according to the criteria used for feldspar by Wright (Orville, 1967). However, finally all the weights were taken to be unity.

For rhodonite and pyroxmangite, indexings were made referring to the data of Borg and Smith (1969), Lindsley and Burnham (1970), Chao et al. (1970), and Ito (private communication, 1973). Indexed powder data of pyroxmangite are shown in Table 1 and Fig. 4. The data were obtained on a strongly oriented sample. The intensified reflections by cleavages as 020 and 200 furnished a guide to the indexing. However, we have to admit that some uncertainty of indexing remains particularly for the reflections with high $2 \theta$ 
values and for those having weak intensities. The indices in Table 1 may not be completely correct, but seem to be acceptable at present for estimating the cell dimensions.

Experimental condition of X-ray powder diffraction for the measurements of cell dimensions are as follows: Mn-filtered Fe $K \alpha$ radition with $30 \mathrm{kV}$ and $10-12 \mathrm{~mA}, \mathrm{GM}$-tube detector, full scale 1000 cps/sec., scanning speed $1 / 4-1 / 8 \mathrm{deg} . / \mathrm{min}$, chart speed $5 \mathrm{~mm} / \mathrm{min}$., receiving slit 0.1 deg., divergent slit 2 deg., and silicon internal standard.

\section{Description of synthetic pyroxenoids}

In discriminating between rhodonite and pyroxmangite with $\mathrm{X}$ ray powder patterns, Yoshimura et al. (1958) pointed out the reflection with $d=2.7 \AA$ as characteristic for rhodonite. It is distinct in the case of small-sized crystals (about $20 \mu$ or below in diameter). In larger crystals the effect of preferred orientation due to cleavages make the discrimination uncertain (Fig. 4).

For comparison between pyroxenoid and clinopyroxene, $\mathrm{X}$-ray powder data of pyroxenoids were reindexed by the setting of clinopyroxene (Fig. 5). Subscripts $\mathrm{p}, \mathrm{r}$, and $\mathrm{c}$ of the indices denote pyroxmangite by Liebau's setting, rhodonite by Buerger's setting, and clinopyroxene by the conventional setting, respectively. Transformation matrixes from Liebau's to Buerger's and from Buerger's to clinopyroxene's setting are $00 \overline{1} / \overline{1} 00 / 110$ and $\overline{1} \overline{1} 0 / 110 / 00 \overline{1}$, respectively.

\section{Rhodonite}

Synthetic rhodonite is pink and the crystals are 10 to $20 \mu$ in length. The largest crystal obtained from the quartz and braunite mixture is $0.1 \mathrm{~mm}$ (Run 603). The $\mathrm{X}$-ray powder patterns are in good agreement with those of natural rhodonite. The cell dimensions and their standard deviations of the product of run 513 are: $a$ 
$7.627 \pm 0.002 \AA, b 11.853 \pm 0.003 \AA, c 6.709 \pm 0.001 \AA, \alpha 92^{\circ} 28^{\prime} \pm 1^{\prime}, \beta 94^{\circ} 25^{\prime}$ $\pm 1^{\prime}, \gamma 105^{\circ} 42^{\prime} \pm 1^{\prime}$ and $V 580.9 \pm 0.2 \AA^{3}$. Calculated density is 3.742 $\mathrm{g} / \mathrm{cm}^{3}$. The infrared absorption spectra were essentially identical with those of a natural rhodonite as shown in Fig. 3 except for an absorption spectrum at $1120 \mathrm{~cm}^{-1}$ in the synthetic material.

Table 1. X-ray powder data of a synthetic pyroxmangite, $\mathrm{MnSiO}_{3}$ (run no. 603).

\begin{tabular}{|c|c|c|c|c|c|c|c|c|c|}
\hline$I$ & $2 \theta$ & $d \AA$ & $d_{\text {cal }} \AA$ & $h k l$ & $I$ & $2 \theta$ & $d \AA$ & $d_{\text {cal }} \AA$ & $h k l$ \\
\hline 21 & $16.04^{\circ}$ & 6.944 & 6.949 & 010 & 2 & $46.34^{\circ}$ & 2. 4603 & 2. 4586 & $21 \overline{4}$ \\
\hline 9 & 16.74 & 6.655 & 6.654 & 100 & 2 & 46.85 & 2. 4350 & 2.4345 & $03 \pi$ \\
\hline 9 & 23.62 & 4.733 & 4.734 & 110 & 5 & 49.42 & 2. 3157 & 2. 3164 & 030 \\
\hline 2 & 26.30 & 4. 258 & 4.254 & $\overline{111}$ & 5 & 49.94 & 2. 2931 & 2. 2928 & $13 \overline{3}$ \\
\hline 3 & 30.19 & 3.720 & 3.717 & $0 \overline{2} 1$ & 2 & 51.83 & 2.2146 & 2. 2143 & 024 \\
\hline 52 & 32.37 & 3.475 & 3.475 & 020 & 8 & 52.48 & 2.1890 & 2.1892 & $3 \overline{1} 2$ \\
\hline 5 & 33.62 & 3.350 & 3.358 & $02 \bar{A}$ & 8 & 53.17 & 2.1630 & 2. 1636 & 301 \\
\hline 19 & 33.85 & 3.327 & 3.327 & 200 & 1 & 54.12 & 2. 1279 & 2. 1287 & 124 \\
\hline 1 & 34.86 & 3.234 & 3.235 & 113 & 2 & 55.68 & 2.0728 & 2.0724 & $2 \overline{3} 2$ \\
\hline 6 & 35.39 & 3.187 & 3.185 & $20 \overline{1}$ & 2 & 56.47 & 2.0462 & 2.0458 & $13 \overline{6}$ \\
\hline 40 & 35.92 & 3.142 & 3. 142 & $2 \overline{1} 2$ & 2 & 58.21 & 1.9901 & 1.9906 & $3 \overline{2} 2$ \\
\hline 13 & 37.13 & 3.043 & 3.042 & 120 & 2 & 62.20 & 1.8741 & 1.8741 & 230 \\
\hline 5 & 37.43 & 3.019 & 3.019 & $2 \overline{1} 3$ & 1 & 62.75 & 1.8593 & 1. 8583 & $04 \overline{2}$ \\
\hline 10 & 38.00 & 2. 9754 & 2.9746 & 014 & 1 & 64.23 & 1.8209 & 1.8218 & $04 \overline{6}$ \\
\hline 34 & 38.12 & 2.9664 & 2.9655 & 210 & 1 & 65.83 & 1.7814 & 1. 7820 & $14 \overline{3}$ \\
\hline 2 & 39.32 & 2.8792 & 2.8793 & 211 & 2 & 68.22 & 1.7262 & 1.7263 & $\overline{3} 22$ \\
\hline 4 & 39.92 & 2.8377 & 2.8361 & 121 & 2 & 68.32 & 1.7240 & 1.7244 & $\overline{2} 32$ \\
\hline 5 & 42.33 & 2.6811 & 2. 6798 & $02 \overline{6}$ & 1 & 69.27 & 1.7032 & 1.7029 & $\overline{1} 26$ \\
\hline 2 & 42.90 & 2.6471 & 2.6464 & $\overline{1} 14$ & 1 & 69.37 & 1.7011 & 1.7014 & $1 \overline{1} 10$ \\
\hline 5 & 43.48 & 2. 6135 & 2.6138 & $2 \overline{2} 2$ & 2 & 70.36 & 1.6799 & 1.6799 & 134 \\
\hline 4 & 45.18 & 2.5200 & 2.5217 & $03 \overline{3}$ & 4 & 71.04 & 1. 6661 & 1. 6662 & 402 \\
\hline \multirow[t]{2}{*}{3} & \multirow[t]{2}{*}{45.42} & \multirow[t]{2}{*}{2.5074} & \multirow[t]{2}{*}{2.5077} & \multirow[t]{2}{*}{$03 \overline{2}$} & 3 & 75.51 & 1.5810 & 1.5804 & $2 \overline{4} 8$ \\
\hline & & & & & 3 & 75.67 & 1.5781 & 1.5779 & 330 \\
\hline
\end{tabular}

In calculation of $d$-spacings, radiations of $\mathrm{Fe} K \alpha(\lambda=1.93728 \AA)$ and $\mathrm{Fe}$ $K \alpha_{1}(\lambda=1.93597 \AA)$ were used for reflections smaller and larger than $40^{\circ}$ in $2 \theta$, respectively. 
Hydrothermal crystallization of $\mathrm{MnSiO}_{3}$ polymorphs

Table 2. Experimental data for the composition $\mathrm{MnSiO}_{3}$.

\begin{tabular}{|c|c|c|c|c|c|}
\hline Run & $\begin{array}{l}\text { Starting } \\
\text { material }\end{array}$ & $\mathrm{P}_{\text {total }}=\mathrm{kb}_{\mathrm{H}_{2} \mathrm{O}}$ & $\begin{array}{l}\text { Temp. } \\
{ }^{\circ} \mathrm{C}\end{array}$ & $\begin{array}{c}\text { Duration } \\
\text { days }\end{array}$ & Products \\
\hline $\begin{array}{l}690 \\
692 \\
691 \\
696\end{array}$ & $\begin{array}{l}A \\
B \\
C \\
A\end{array}$ & $\begin{array}{l}2 \\
\text { " } \\
\text { " }\end{array}$ & $\begin{array}{c}650 \\
" 1 \\
" \\
"\end{array}$ & $\begin{array}{c}1 / 4 \\
\prime \prime \\
1 \\
1\end{array}$ & $\begin{array}{l}\mathrm{Q}+\mathrm{Tp}+\mathrm{CP} 1 \\
\mathrm{CP} 1 \\
\mathrm{Q}+\mathrm{Br} \\
\mathrm{Pm}\end{array}$ \\
\hline $\begin{array}{l}698 \\
708 \\
602\end{array}$ & $\begin{array}{l}\mathrm{B} \\
\mathrm{C} \\
\mathrm{A}\end{array}$ & $\begin{array}{l}\text { " } \\
\text { " }\end{array}$ & $\begin{array}{l}\prime \prime \\
662\end{array}$ & $\begin{array}{l}\prime \prime \\
5\end{array}$ & $\begin{array}{l}\mathrm{CP} 1 \\
\mathrm{Q}+\mathrm{Br}+\mathrm{CP} 1 \\
\mathrm{Pm}\end{array}$ \\
\hline $\begin{array}{l}620 \\
621 \\
622 \\
626 \\
627 \\
628\end{array}$ & $\begin{array}{l}\text { A } \\
\text { D } \\
B \\
\text { A } \\
\text { D } \\
B\end{array}$ & $\begin{array}{l}2 \\
\text { " } \\
\text { " } \\
\text { " } \\
\text { " }\end{array}$ & $\begin{array}{l}748 \\
" \prime \\
" 1 \\
752 \\
" \prime \\
" 1\end{array}$ & $\begin{array}{l}1 / 4 \\
\prime \prime \\
\prime \prime \\
1 \\
\prime \prime \\
\prime \prime\end{array}$ & $\begin{array}{l}\mathrm{Pm}+\mathrm{Rh} \\
\mathrm{Q}+\mathrm{Br} \\
\mathrm{CP} 2 \\
\mathrm{Rh} \\
\mathrm{Pm}>\mathrm{Br}+\mathrm{Rh} \\
\mathrm{CP} 2>\mathrm{Rh}+\mathrm{Pm}\end{array}$ \\
\hline $\begin{array}{l}366 \\
607 \\
638 \\
618 \\
603 \\
616\end{array}$ & $\begin{array}{l}A \\
A \\
B \\
B \\
D \\
B\end{array}$ & $\begin{array}{l}4 \\
11 \\
3.6 \\
3.3 \\
3 \\
1 "\end{array}$ & $\begin{array}{l}500 \\
680 \\
722 \\
745 \\
698 \\
728\end{array}$ & $\begin{array}{l}4 \\
\prime \prime \\
8 \\
3 \\
4 \\
\prime \prime\end{array}$ & $\begin{array}{l}\mathrm{Pm}+\mathrm{Q}+\mathrm{T} p \\
\mathrm{Pm} \\
\mathrm{Pm} \\
\mathrm{Rh}>\mathrm{CP} 2 \\
\mathrm{Pm} \\
\mathrm{Pm}>\mathrm{Rh}\end{array}$ \\
\hline $\begin{array}{l}710 \\
711 \\
601 \\
507 \\
513\end{array}$ & $\begin{array}{l}A \\
C \\
D \\
A \\
A\end{array}$ & $\begin{array}{l}2 \\
" 1 \\
" \prime \\
" \prime\end{array}$ & $\begin{array}{l}450 \\
\prime \prime \\
662 \\
700 \\
725\end{array}$ & $\begin{array}{r}21 \\
\prime \prime \\
5 \\
2 \\
\prime \prime\end{array}$ & $\begin{array}{l}\mathrm{CP} 1+\mathrm{Tp}+\mathrm{Q} \\
\mathrm{CP} 1>\mathrm{Br}+\mathrm{Q} \\
\mathrm{Pm} \\
\mathrm{Rh}>\mathrm{Pm} \\
\mathrm{Rh}\end{array}$ \\
\hline $\begin{array}{l}713 \\
714 \\
597 \\
598 \\
599 \\
600\end{array}$ & $\begin{array}{l}A \\
C \\
D \\
A \\
D \\
A\end{array}$ & $\begin{array}{l}1 \\
\text { " } \\
\text { " } \\
\text { " }\end{array}$ & $\begin{array}{c}450 \\
" 1 \\
650 \\
\prime \prime \\
700 \\
" 1\end{array}$ & $\begin{array}{r}21 \\
" \prime \\
8 \\
\prime \prime \\
" \\
\prime \prime\end{array}$ & $\begin{array}{l}\mathrm{Q}+\mathrm{Tp}>\mathrm{CP} 1 \\
\mathrm{CP} 1>\mathrm{Q}+\mathrm{Br} \\
\mathrm{Pm} \\
\mathrm{Pm}>\mathrm{Rh} \\
\mathrm{Pm}>\mathrm{Rh} \\
\mathrm{Rh}>\mathrm{Pm}\end{array}$ \\
\hline $\begin{array}{l}611 \\
612 \\
634 \\
313 \\
671 \\
673 \\
630\end{array}$ & $\begin{array}{l}\text { A } \\
\text { B } \\
A \\
\text { NPm } \\
\text { NPm } \\
\text { SPm } \\
\text { SPm }\end{array}$ & $\begin{array}{l}0.5 \\
1 " \\
1 " \\
4 \\
2 \\
2 \\
3\end{array}$ & $\begin{array}{c}667 \\
\prime \prime \\
700 \\
600 \\
748 \\
\prime \prime \\
750\end{array}$ & $\begin{array}{r}12 \\
\prime \prime \\
7 \\
4 \\
5 \\
\prime \prime \\
3\end{array}$ & $\begin{array}{l}\mathrm{Pm}>\mathrm{Rh} \\
\mathrm{CPl} \\
\mathrm{Pm}>\mathrm{Rh} \\
\mathrm{Pm} \\
\mathrm{Rh} \\
\mathrm{Rh} \\
\mathrm{Rh}\end{array}$ \\
\hline
\end{tabular}

A : carbonate mixture. $\mathrm{B}$ : glass. $\mathrm{C}$ and $\mathrm{D}$ : quartz and braunite mixture. $\mathrm{Q}$ : quartz. $\mathrm{Tp}$ : tephroite. $\mathrm{Br}$ : braunite. $\mathrm{Pm}$ : pyroxmangite. $\mathrm{Rh}$ : rhodonite. $\mathrm{CP} 1$ and $\mathrm{CP} 2$ : clinopyroxene-like phases at $650^{\circ}$ and $750^{\circ} \mathrm{C}$, respectively. SPm: synthetic pyroxmangite. NPm: natural pyroxmangite from the Takamori mine. 


\section{Pyroxmangite}

Pyroxmangites synthesized from the carbonate mixture and from glass are pinkish crystals of 10 to $30 \mu$ in length and those from the quartz and braunite mixture grow up to $0.3 \mathrm{~mm}$. The latter form beautiful red crystals under a binocular microscope. The X-ray powder patterns of synthetic pyroxmangites are shown in Fig. 1, and the data are listed in Table 1. The cell dimensions and their standard deviations are : $a 6.722 \pm 0.002 \AA, b 7.600 \pm 0.002 \mathrm{~A}$, c $17.461 \pm 0.005 \AA, \alpha 113^{\circ} 48^{\prime} \pm 1^{\prime}, \beta 82^{\circ} 16^{\prime} \pm 1^{\prime}, \gamma 94^{\circ} 46^{\prime} \pm 1^{\prime}$ and $V 808.2$ $\pm 0.4 \AA^{3}$. Calculated density is $3.774 \mathrm{~g} / \mathrm{cm}^{3}$. The infrared absorption spectrum (Run 602) is in good agreement with a natural specimen as shown in Fig. 2.

\section{Process of crystallization}

In order to investigate the process of crystallization of $\mathrm{MnSiO}_{3}$ polymorphs, three different starting materials were prepared: carbonate mixture, quartz and braunite mixtures, and glasses. X-ray powder patterns and infrared absorption spectra of some products are shown in Figs. 1-3.

(1) At $650^{\circ} \mathrm{C}$ and $2 \mathrm{~kb}$

The first phase that appeared in the 6 hours run of the carbonate mixture, was an assemblage of quartz and tephroite. When the duration of reaction was prolonged, the metastable phase gradually disappeared and the pyroxmangite phase developed subsequently. The reaction seemed to have been completed in 24 hours, and no transformation from pyroxmangite to another phase could be detected in longer runs.

From the quartz and braunite mixture, pyroxmangite grew directly without growth of an intermediate phase. The reaction completed in about 2 days. Using the seed of pyroxmangite, the good crystal gradually grew up to $1 \mathrm{~mm}$. 


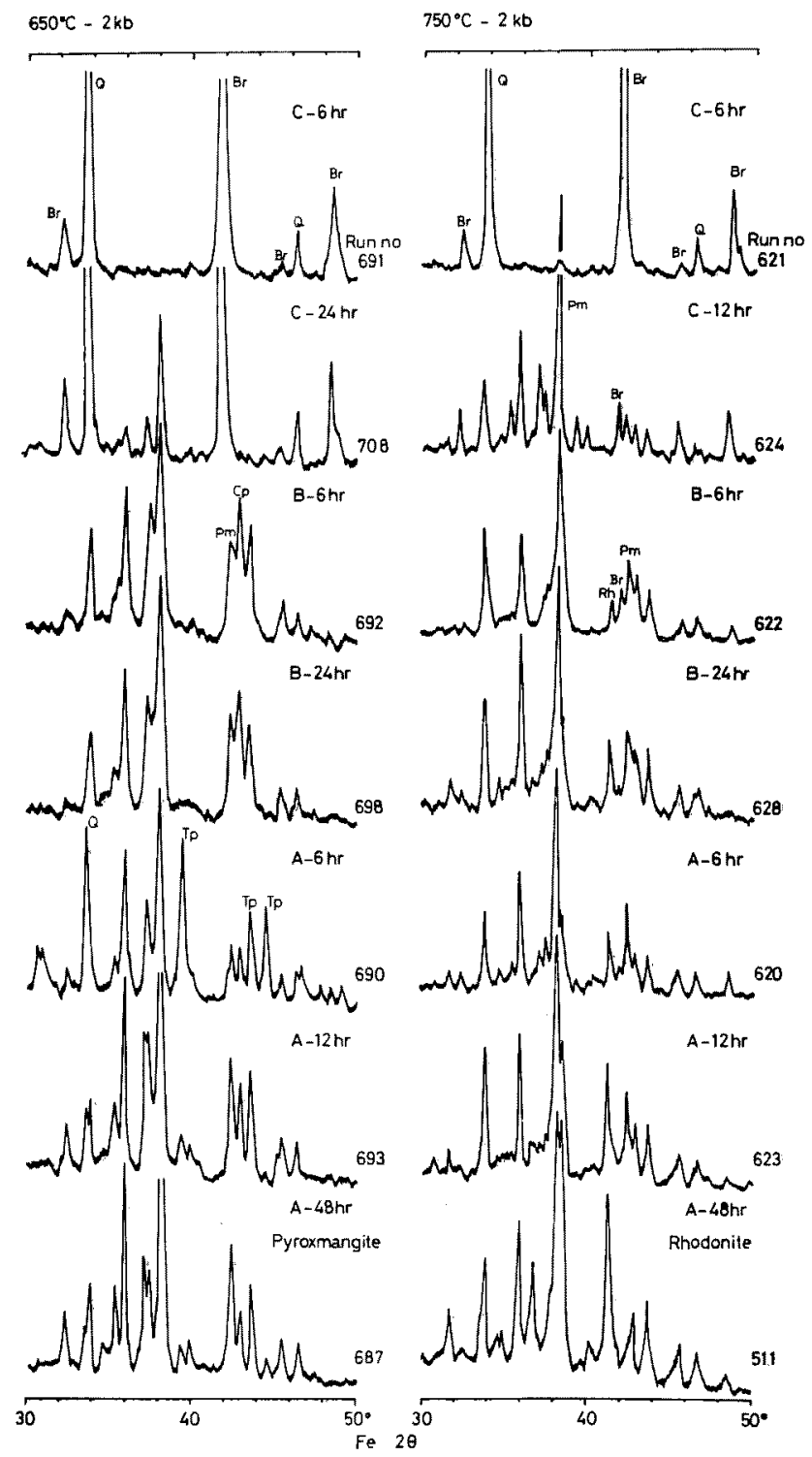

Fig. 1. X-ray powder patterns of hydrothermal products at $650^{\circ} \mathrm{C}$ and $750^{\circ} \mathrm{C}$ under a pressure of $2 \mathrm{~kb}$. On abbreviations in all figures, refer to the footnote in Table 2 . 


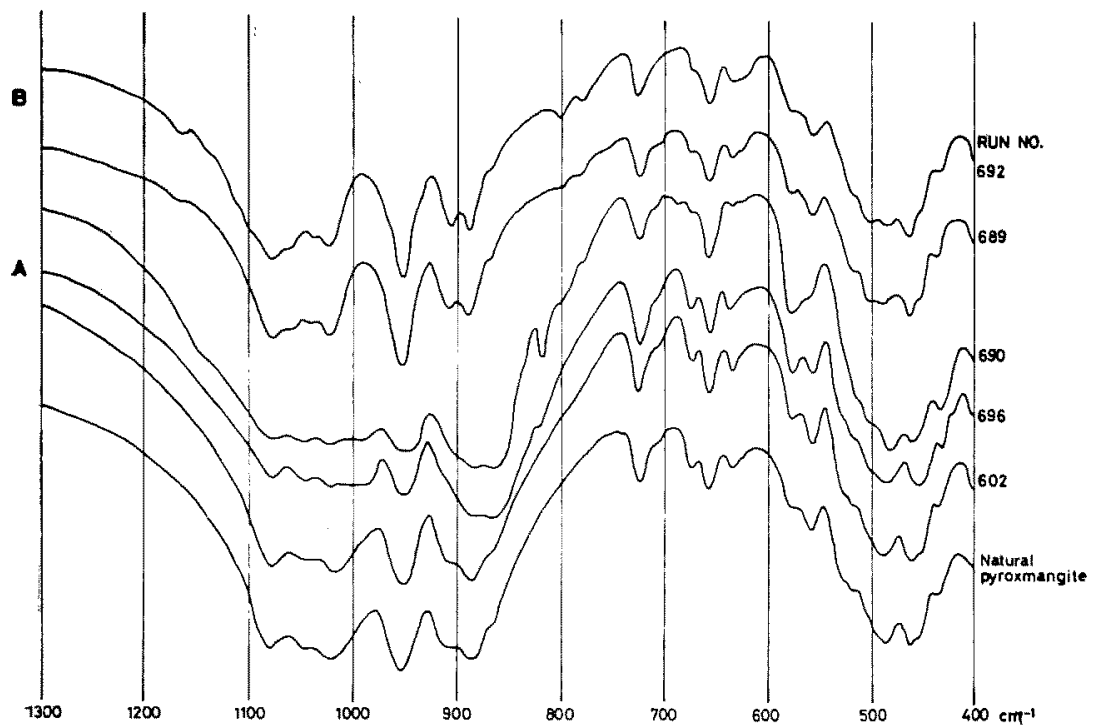

Fig. 2. Infrared absorption spectra of hydrothermal products at $650^{\circ} \mathrm{C}$ and $2 \mathrm{~kb}$.

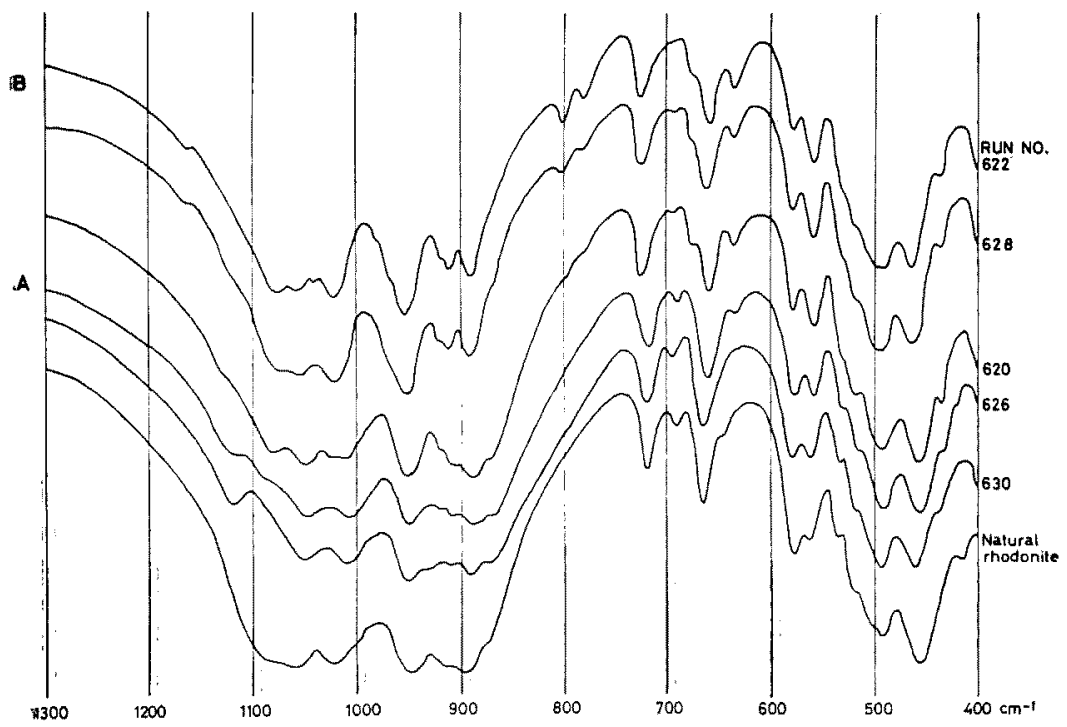

Fig. 3. Infrared absorption spectra of hydrothermal products at $750^{\circ} \mathrm{C}$ and $2 \mathrm{~kb}$. 
In the glass, the first phase recognized after 6 hours has four strong peaks in the X-ray powder pattern, similar to those of clinopyroxene: $(200)_{p},(2 \overline{1} 2)_{p},(210)_{p}$ and $(1 \overline{1} 4)_{p}$ correspond to $(220),(131)$, (310) and $(02 \overline{4})$ for clinopyroxene's setting, respectively. These indices are assigned respectively to $(220)_{c},(221)_{c},(310)_{c}$ and $(131)_{c}$ of clinopyroxene, as shown in Fig. 5. The intensity of $d(\overline{1} 14)_{\mathrm{p}}=2.64 \AA$ is significantly stronger than that of $d(02 \overline{6})_{p}=2.67 \mathrm{~A}$, indicating a characteristic line of pyroxmangite. In such assignment of peaks, it seems more reasonable to consider the first phase to be clinopyroxene rather than pyroxmangite. The latter phase seems to have a more loose structure than that of $\mathrm{MnSiO}_{3}$ III after Akimoto and Syono (1972), because powder lines of $\mathrm{MnSiO}_{3}$ III slightly shift to the higher angle side of $2 \theta$. In infrared absorption spectra of the products, the presence of absorption at $625 \mathrm{~cm}^{-1}$ and the sharpness of absorption at $960 \mathrm{~cm}^{-1}$ agree with the properties of clinopyroxene. The pyroxmangite which appeared as the second phase prevailed in the products after 2 days and the transformation was completed in 3 days.

(2) At $750^{\circ} \mathrm{C}$ and $2 \mathrm{~kb}$

The synthetic product from the carbonate mixture after 6 hours was composed mainly of pyroxmangite (inter-mediate phase) with a small amount of rhodonite. After 24 hours, the pyroxmangite phase disappeared and the product consisted of rhodonite only. This crystallization into rhodonite seems to be more rapid than that from other starting materials.

From the quartz and braunite mixture, no new phase was detected after 6 hours run. The crystallization of pyroxmangite was noticed in the products after 12 hours. After 24 hours, the pyroxmangite phase was recognized with no relict of the starting material, and the strongest $X$-ray reflection of rhodonite $(d=2.73 \AA)$ was observed as a very faint peak. The good crystal of pyroxmangite thus obtained, though metastable, required more than 4 
days to transform into rhodonite.

In the glass, the first phase obtained after 6 hours shows three strong X-ray reflections of $(200)_{p},(2 \overline{1} 2)_{p}$ and $(210)_{p}$ and a broad one of $(0 \overline{2} 6)_{p}$. The reflection of $(0 \overline{2} 6)_{p}$ was stronger than that at $650^{\circ} \mathrm{C}$. The product seems to have a structure closer to that of pyroxmangite rather than clinopyroxene. In both products after 6 and 24 hours, no difference was found except for the slight increase of intensity of $(024)_{r}$ in the latter. The infrared spectra of the product after 24 hours also show the character resembling clinopyro-

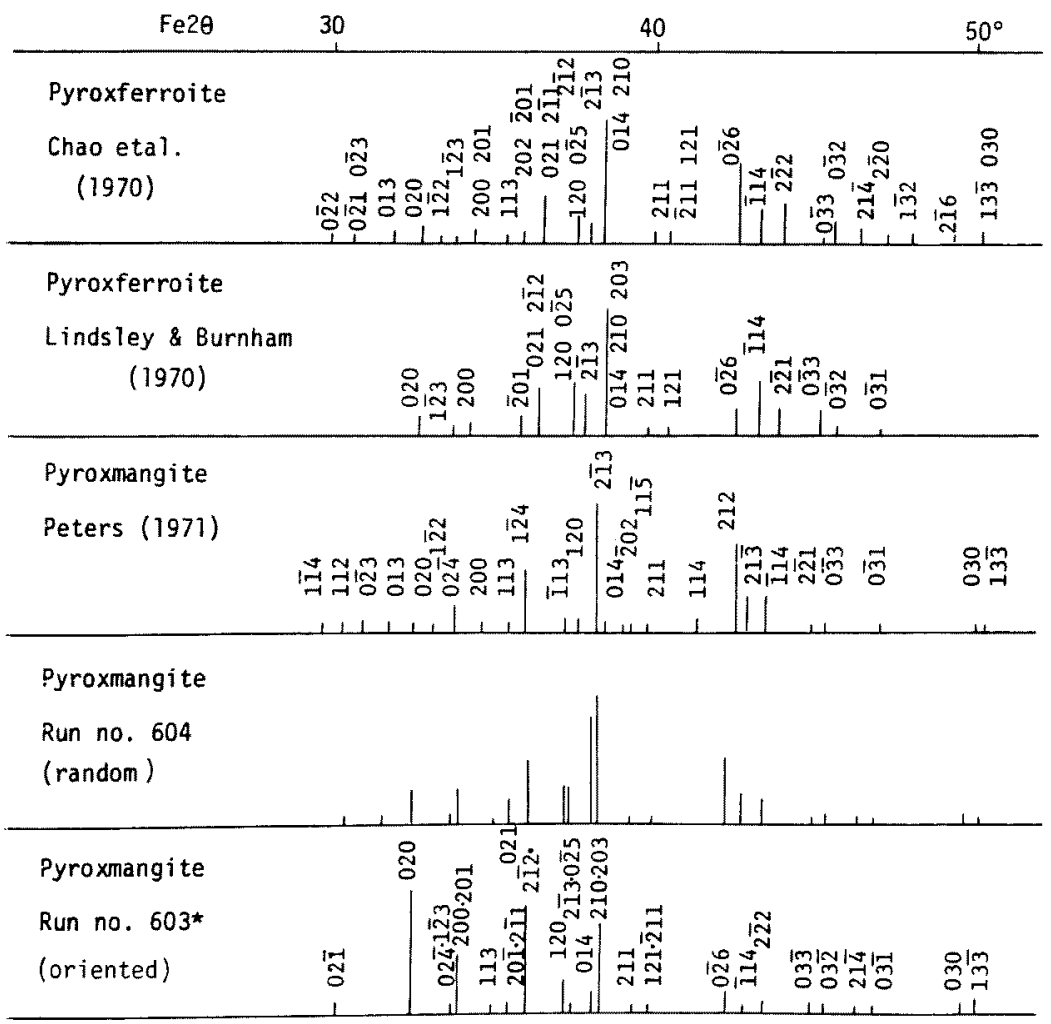

Fig. 4. Indexing of X-ray powder patterns of pyroxferroite and pyroxmangite. 


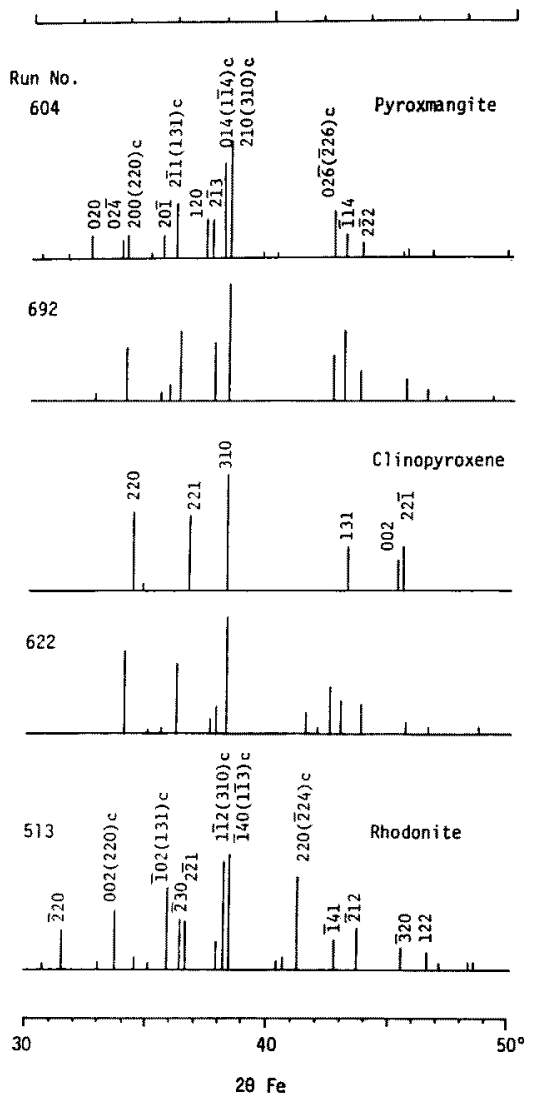

Fig. 5. X-ray powder patterns of the intermediate phases (Runs 692 and 622 ).

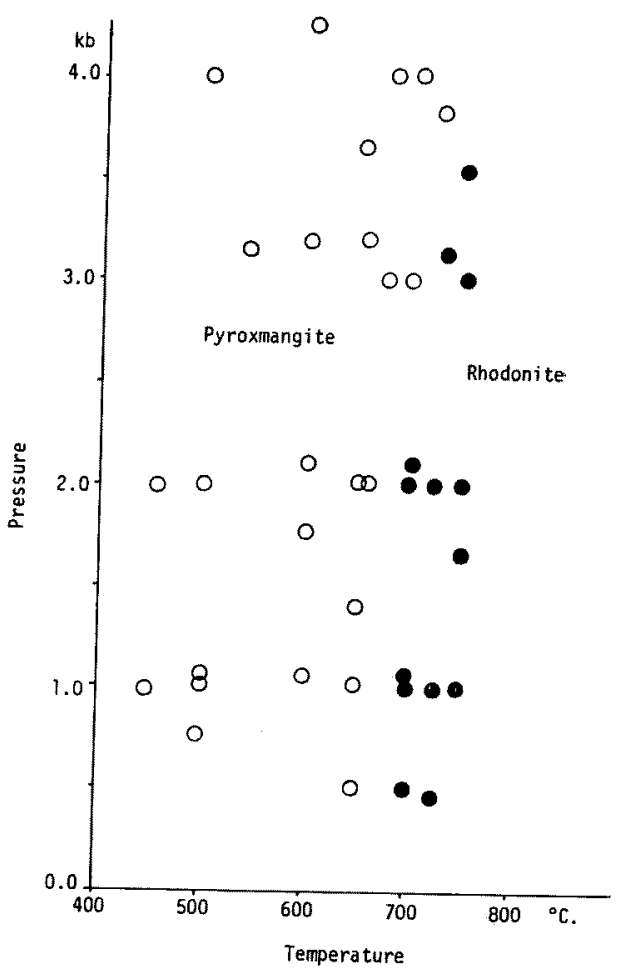

Fig. 6. Representation of run products with $\mathrm{MnSiO}_{3}$ composition synthesized under water pressure.

xene. The significant absorption at $960 \mathrm{~cm}^{-1}$, which is a characteristic band of clinopyroxene, may indicate the growth of clinopyroxene in the earlier product. The pure rhodonite phase was obtained with the 4 days run. 


\section{Discussion}

Hydrothermal products of $\mathrm{MnSiO}_{3}$ were identified in the temperature range of $500^{\circ} \mathrm{C}$ to $750^{\circ} \mathrm{C}$ and in the pressure from 0.5 to $4.0 \mathrm{~kb}$. Products obtained under various conditions were plotted on the temperature versus pressure diagram (Fig. 6). As shown in the figure, pyroxmangites were synthesized in the temperature lower than about $700^{\circ} \mathrm{C}$ and rhodonites in the higher temperature. Synthetic and natural pyroxmangites transform into rhodonite at about $700^{\circ} \mathrm{C}$ as temperature rises. The reverse reaction from rhodonite to pyroxmangite were tried, but no transformation was recognized by X-ray examination. Accordingly, the boundary between rhodonite and pyroxmangite in the figure is a tentative one and may not be a equilibrium one (Huebner, 1971).

Peters $(1971,1973)$ determined the lower stability limit of pyroxmangite under water and carbon dioxide pressure or both. The present study of reaction rates, though qualitative, reveals that the carbonate mixture is more reactive than the other starting materials and the reaction progresses easily. These results suggest that pyroxmangite would be stable under hydrothermal condition, which is not in line with the results obtained under high pressure condition by Akimoto and Syono (1972). One of the reasons for discrepancy may possibly be related to the difference in crystal growth condition such as wet or dry. Although the results obtained under hydrothermal condition are favorable to explain the natural occurrence of pyroxmangite, further study including the reverse reaction from rhodonite to pyroxmangite should be undertaken in order to confirm the stability field of pyroxmangite. Some additional experiments in buffered conditions were also tried, but no difference was recognized with the above results.

Structural changes in the transformation from pyroxmangite (Siebenerketten) to rhodonite (Fünferketten) with rising temperature 
may be regarded as a decrease of the number of silica tetrahedra in a repeat unit of a single chain. Such structural change has been known in the transformation of natural calcium-bearing rhodonite into bustamite (Dreierketten) with rising temperature (Glasser and Glasser, 1961).

The transformation from pyroxene (Zweierketten) into pyroxenoid also has been known to occur with rising temperature: from johanssenite (Zweierketten) into bustamite (Dreierketten) (Schaller, 1938; Morimoto et al., 1966), from magnesian manganese clinopyroxene into magnesian pyroxmangite (Ito, 1972; Momoi, 1973). The similar phenomenon is observed in the process of crystallization of pyroxmangite, as mentioned previously.

According to the structural interpretation that pyroxene is regarded as a kind of pyroxenoid having a side-step after an infinite repetition of two silica-tetrahedra unit, as considered by Burnham (1966) and Akimoto and Syono (1972), it can be stated that in the polymorphic transformation of $\mathrm{MnSiO}_{s}(e . g$. pyroxene $\rightarrow$ pyroxmangite $\rightarrow$ rhodonite), the decrease of silica tetrahedra in a repeat unit of a single chain is considered to occur with decreasing pressure (Akimoto and Syono, 1972) or with rising temperature.

Acknowledgments-The writer expresses his sincere thanks to Prof. H. Shirozu of Kyushu University for his critical reading of the manuscript, and Mr. Y. Aoki and Dr. T. Watanabe of Kyushu University for their interests and encouragement. The preliminary experiments were carried out at Osaka University under the kind guidance of Profs. M. Koizumi and S. Kume. Thanks are given to Dr. D.E. Appleman for the use of the indexing program which was introduced by Dr. H. Takeda of University of Tokyo. The calculations were performed at the Computation Center of Kyushu University. The research was financed in part by the Ministry of Education with Grant in Aid for Scientific Researches. 


\section{REFERENCES}

Aкimoto, S. \& Syono, Y. (1972) Amer. Miner., 57, 76.

Borg, I. Y. \& Smith, D. K. (1969) Geol. Soc. Amer. Mem., 122, p. 896.

Burnham, C. W. (1970) Science, 154, 513.

Chao, E.C.T., Minkin, J.A., Frondel, C., Klein, C. Jr., Drake, J.C., Fuchs, L., Tani, B., Smith, J.V., Anderson, A.T., Moore, P.B., Zechman, G.R. Jr., Traill, R. J., Plant, A.G., Douglas, J.A. V. \& Dence, M.R. (1970) Proc. Apollo 11 Lunar Sci. Conf., 1, 65.

Eugster, H.P. (1957) Jour. Chem. Phys., 26, 1760.

Evans, H.T. Jr., Appleman, D.E. \& Handwerker, D.S. (1963) Amer.

Cryst Assoc. Meeting, Cambridge, Program and Abstract, 42.

Glasser, F.P. (1958) Amer. Journ. Sci., 256, 398.

Glasser, L.S. \& Glasser, F.P. (1961) Acta Cryst., 14, 818.

HuebNer, J.S. (1971) in Research Techniques for High Pressure and High

Temperature, G.C. ULMER, ed., New York, Springer Verlag, 123.

ITo, J. (1972) Amer. Miner., 57, 865.

ITO, J. (1973) Miner. Journ., 7, 45.

Lindsley, D. H. \& Burnham, C.M. (1970) Science, 168, 364.

ORVILLE, P.M. (1967) Amer. Miner., 52, 55.

Momor, H. (1968) Journ. Miner. Soc. Japan, 8, sp. 2, 1.

Mомог, H. (1968) Sci. Rept., Fac. Sci., Kyushu Univ., 9, 59.

Momor, H. (1970) Journ. Miner. Soc. Japan, 10, 82.

MomoI, H. (1973) Sci. Rept., Fac. Sci., Kyushu Univ., 11, 251.

Morimoto, N., Koto, K. \& Shinohara, T. (1966) Miner. Journ., 5, 44.

Peters, Tj. (1971) Contr. Miner. Petrol., 32, 267.

Peters, Tj., Schwander, H. \& Trommsdorff, V. (1973) Contr. Miner. Petrol., 42, 325.

Schaller, W. T. (1938) Amer. Miner., 23, 575.

SAKurai, T. (1967) ed. Universal Crystallographic Computation Programs System (UNICS). Cryst. Soc. Japan.

Yoshimura, T., Shirozu, H. \& Hirowatari, F. (1958) Journ. Miner. Soc. Japan, 3, 457.

Received January 28, 1974 ; revised March 31, 1974. 